\title{
OPTIMAL MIX OF PENALTIES IN A PRINCIPAL-AGENT MODEL UNDER DIFFERENT INSTITUTIONAL ARRANGEMENTS
}

\author{
Dietrich Earnhart*
}

Abstract-This paper uses principal-agent theory to examine the optimal mix of monetary- and resource-based penalties in two institutional settings: a market economy and a centrally planned economy. In a centrally planned economy, an agent's wealth depends mostly on real resources and little on monetary resources; therefore, monetary-based penalties have less penalizing power than do resource-based penalties. Based on this premise, theory generates hypotheses regarding differences in the optimal mix of penalty types between the two economic systems. This paper empirically tests these hypotheses using data from the Czech Republic regarding enforcement responses to water-damaging accidents (such as oil spills).

\section{Introduction}

T HIS paper considers the optimal mix of penalties in two different types of economic systems: a market economy and a centrally planned economy. In either economic system, the operations of an enterprise may cause an accident, such as an oil spill, which imposes costs on society. These costs prompt a government authority to establish a liability law to deter the enterprise from causing an accident. The liability law imposes two types of penalties: monetarybased fines and resource-based remediation requirements (such as the mandatory removal of oil-soaked soil). However, the relative value of money differs between the two economic systems, which causes the two types of penalties to generate different degrees of deterrence, which thus alters the optimal mix of penalties.

A principal-agent framework effectively structures the interaction between an enterprise and government authority (Shavell, 1979) and facilitates the exploration of the optimal penalty mix (Cohen, 1987). Accordingly, this paper examines the principal-agent relationship between an agent, who engages in a risky activity that causes stochastic externalities, and a principal, who seeks to control these events by penalizing the agent. Unlike previous research (Cohen, 1987), this analysis examines the principal-agent relationship in two different institutional settings: a market economy, where the agent is motivated by monetary proceeds (profits), and a centrally planned economy, where the agent is motivated by output (plan fulfillment) and inputs (hoarding). The principal-agent relationship differs substantially between these two institutional settings.

Received for publication July 18, 1997. Revision accepted for publication November 10, 1999.

* University of Kansas.

I would like to thank the following people for their advice and insight: Martin David, Kathleen Segerson, Larry Samuelson, Dan Bromley, Arik Levinson, James Buss, Ben Slay, Kathryn Nantz, participants of the Public Workshop at the University of Wisconsin-Madison, discussants at the Association of Environmental and Resource Economists annual meetings, and two anonymous referees. Financial support of my research in the Czech Republic was given by the University of Pittsburgh, the Center for Economic Research and Graduate Education (CERGE), and the United States Agency for International Development (US AID). Needless to say, the material presented here represents the viewpoint of only the author.
Due to soft budget constraints ${ }^{1}$ and agents' (enterprises') desires to fulfill the "plan" in a centrally planned economy, agent wealth depends mostly on real resources and only to a limited degree on monetary resources. Therefore, in a centrally planned economy, monetary-based penalties have much less penalizing power than do resource-based penalties. Given that the principal is trying to provide the proper incentives to control stochastic externalities in both economic systems, the principal-agent framework generates testable hypotheses concerning the use of each penalty component in the two economic systems. If economic restructuring alters the principal's objective, in addition to the value of money, then the principal-agent framework generates modified hypotheses concerning the relative use of each penalty component.

As an empirical test of these hypotheses, this paper examines data on the enforcement of water-protection laws in the Czech Republic from 1988 to 1992, a period that spans both aforementioned economic systems. ${ }^{2}$ In particular, this paper analyzes enforcement actions taken in response to water-damaging accidents (such as oil spills). ${ }^{3}$ To capture these actions, this study exploits unique and rich data maintained by the main enforcer of water laws, Czech Water Inspection.

The rest of this paper is organized as follows. Section II broadly addresses principal-agent relationships in different economic systems and articulates the hypotheses. Section III describes the Czech enforcement process and the database on accidents. Section IV provides econometric analysis of enforcement actions and empirically tests the hypotheses. Section V summarizes the results.

\section{Principal-Agent Framework}

\section{A. Principal-Agent Relationships in Different Economic Systems}

The principal-agent relationship associated with the control of stochastic externalities is substantially different in a centrally planned economy than it is in a market economy. Although many aspects of the economic system affect the relationship, this analysis focuses on the agent's composition of wealth, especially its influence on the effectiveness of individual components within the penalty mechanism available to the principal. In a market economy, money has the

\footnotetext{
${ }^{1}$ An enterprise faces a soft-budget constraint when it does not need to cover its long-run costs (for example, when state subsidies allow an insolvent enterprise to remain in business).

${ }^{2}$ For the purposes of this analysis, the years 1988-1990 are regarded as a central planned economy and the years 1991-1992 as a transitional market economy, as noted in section IIIA.

${ }^{3}$ Certainly, some of these events were not caused accidently. Nevertheless, the principal-agent model still appropriately applies.
} 
ability to command real resources for the agent's use so that the agent's wealth depends on money through profits. Because both monetary fines and the costs of required remediation reduce profits and thus wealth, they must similarly penalize an agent. ${ }^{4}$ In a transitional market economy, in which economic activities are not centrally managed yet market institutions are incomplete, money has a greater ability to command real resources (that is, it affects wealth more strongly) than in a centrally planned economy.

In a centrally planned economy, the standard assumptions concerning money's ability to command real resources and the associated agent's composition of wealth appear to be violated. Under centralized arrangements, the "plan" allocated most resources to enterprises (agents). Although monetary funds were needed for the "purchase" of these production inputs, universal subsidization of enterprises generally provided the necessary funds. Because central planning did not allocate resources perfectly and shortages of essential inputs existed, enterprise managers frequently desired an exchange of real resources. In response, enterprise managers established elaborate webs of personal relationships for trade in resources, mostly according to a barter system (Grossman, 1977; Ericson, 1984). Thus, money played a relatively minor role at the enterprise level.

Given universal subsidization and a second economy based mostly on barter, enterprise management had little incentive to maximize profits; instead, enterprise management had significant incentives to fulfill the plan because bonuses, tenure, and status in the Communist party hinged on plan fulfillment and past fulfillments (Litwack, 1991). Thus, rather than money or profits, enterprise management sought real resources in order to fulfill the plan; that is, the agent's wealth depended primarily on real resources and to a much less degree on money.

Money's limited ability to command resources and the agent's desire for plan fulfillment imply different penalizing powers for monetary- and resource-based penalties under central planning. Monetary-based fines are neutralized by subsidization, while resource-based remediation requirements divert real resources away from production. Thus, monetary fines should have much less penalizing power relative to remediation in a centrally planned economy. Moreover, monetary fines should have much less penalizing power under central planning relative to a market economy. ${ }^{5}$

\footnotetext{
${ }^{4}$ This study does not explore reputational penalties borne by agents. See Karpoff and Lott (1993) for analysis on these penalties.

${ }^{5}$ This logic implicitly assumes that the importance of real resources is constant between the two economic systems. In reality, economic restructuring may also affect the importance of real resources. For example, reduced commercial opportunities in the transitional market economy of the Czech Republic may cause resources to sit idle, thus reducing their importance. If true, this change would actually bolster the perspective that the importance of monetary resources relative to real resources increased in the market economy. In general, we need only assume that any increase in the importance of real resources not exceed the purported increase in the importance of monetary resources.
}

The optimal penalty mix depends on the absolute penalizing power of monetary fines under central planning. Two cases exist:

case 1: monetary fines have some penalizing power under central planning.

case 2: monetary fines have no penalizing power under central planning.

Under case 1, government authorities can maintain the real penalizing power of monetary fines by inflating their nominal levels. Therefore, in real terms, the absolute and relative use of monetary and remedial penalties does not differ between the two economic systems, only the nominal level of monetary fines. This logic generates hypothesis 1: nominal monetary fine levels, conditional upon remediation levels, are greater under central planning relative to a market economy, while remediation is required evenly across economic systems. Under case 2, authorities cannot maintain the real penalizing power of monetary fines; instead, it collapses to zero. Therefore, the optimal penalty mix under central planning eliminates monetary fines and relies exclusively on remedial penalties. ${ }^{6}$ This logic generates hypothesis 2: remediation requirements should be emphasized under central planning relative to a market economy, while monetary fines should be emphasized, conditional upon the level of remediation, in a market economy relative to a centrally planned economy. (Earnhart (1999) provides a formal principal-agent model that generates these hypotheses.)

This logic also extends to the likelihood of penalty imposition as long as imposition is costly. First, consider the imposition of each penalty type separately. Under case 1, monetary fines and remediation requirements are equally likely between the two economic systems. This prediction represents a variant of hypothesis 1 and is noted as hypothesis $1 \mathrm{~A}$. Under case 2 , monetary fines are less likely in a centrally planned economy than in a market economy, while remediation requirements are more likely in a centrally planned economy than in a market economy. This prediction represents a variant of hypothesis 2 and is noted as hypothesis 2A. Second, consider the imposition of the two penalty types jointly. Certain events may require only remediation, in which the benefits of fine imposition do not warrant the cost. Some events may not warrant remediation, in which only a monetary fine is sufficient. Other events may require both penalties or neither penalty. Given this perspective, under case 1, the sole use of either penalty and the joint use of both penalties is equally likely between the two economic systems; this prediction constitutes hypothesis $1 \mathrm{~B}$.

\footnotetext{
${ }^{6}$ This conclusion does not rely on monetary fines being completely worthless under central planning. If monetary fines have an upper limit (which is true in the case of water-damaging accidents in the Czech Republic), then monetary fines need only be sufficiently worthless to make their imposition unproductive. In other words, the benefits of imposing even the highest possible fine are less then the cost of imposition.
} 
Under case 2, the sole use of monetary fines and the joint use of both penalties is less likely in a centrally planned economy than in a market economy, while the sole use of remediation requirements is more likely in a centrally planned economy than in a market economy; this prediction constitutes hypothesis $2 \mathrm{~B}$.

\section{B. Principal's Objective Differs between Economic Systems}

The logic used to generate these hypotheses assumes that the objective of the principal does not differ between the two economic systems. In reality, the Czech government authority's objective may differ greatly. To establish a vibrant market economy of thriving private enterprises, the Czech principal may have increased its concern for preventive effort expended by and penalties imposed upon enterprises (agents). Conversely, the transformation of the economic system roughly coincided with a transformation of the political system from a communist system to a democratic system. This transformation generated a dramatic change in the priorities given to environmental protection. Although the communist regime often disregarded the environment, the democratic regime, upon ascendance, took major steps to improve the environment (Czech Ministry of the Environment, 1990). These substantially different environmental perspectives may have prompted the Czech principal to increase its concern for averting stochastic externalities and for reducing environmental damages. ${ }^{7}$ In either case, a change in the principal's objective would alter the chosen levels and imposition likelihoods of penalties, ceteris paribus. In the first case, levels and likelihoods of both monetary fines and remediation requirements would be lower in the market economy than in the centrally planned economy, ceteris paribus; in the second case, the opposite result follows.

Similarly, the principal-agent logic assumes that the principal's objective concerns only societal wealth. From a political-economy perspective, the principal may also wish to appear tough on enforcement. In particular, Czech water authorities may wish to impose remediation requirements and monetary fines to display their environmental consciousness to the Czech citizenry and Western countries, a practice called "show." Obviously, this additional concern would prompt the principal to increase the chosen level of each penalty and its likelihood of imposition. In this regard for show, the principal's objective may also differ between the two economic systems. Most likely, the communist regime possessed greater desire for show, causing the levels and likelihoods of both penalties to be higher in the centrally planned economy than in the market economy, ceteris paribus.

\footnotetext{
${ }^{7}$ Although the environmental perspectives apparently differ, the waterprotection laws and the rules guiding their enforcement vary little between the two political regimes.
}

Obviously, the original hypotheses may not be robust to these changes. ${ }^{8}$ However, the hypotheses are robust if they are restated in terms of relative penalty use, rather than absolute penalty use. First, consider case 1. Regarding penalty levels, the ratio of remediation level to monetary fine level is greater in the market economy than it is under central planning: hypothesis $1 \mathrm{C}$. Regarding penalty imposition, the following relative uses of penalties are equally likely between the two economic systems:

1. joint use of both penalties relative to the sole use of remediation;

2. the joint use of both penalties relative to the sole use of monetary fines; and

3. the sole use of remediation relative to the sole use of monetary fines.

These predictions constitute hypothesis 1D.

Second, consider case 2. Regarding penalty levels, the ratio of remediation level to monetary fine level is smaller in the market economy than it is in the centrally planned economy, a prediction that constitutes hypothesis $2 \mathrm{C}$. Regarding penalty imposition, the joint use of both penalties is more likely, relative to the sole use of remediation, in the market economy than it is in the centrally planned economy; that is, conditional on the imposition of a remediation requirement, a monetary fine is more likely in the market economy. Conversely, the joint use of both penalties is less likely, relative to the sole use of monetary fines, in the market economy than in the centrally planned economy; that is, conditional on the imposition of a monetary fine, a remediation requirement is less likely in the market economy. Similarly, the sole use of remediation, relative to the sole use of monetary fines, is less likely in the market economy than it is in the centrally planned economy; that is, conditional on the imposition of a penalty, remediation is less likely and a monetary fine more likely in the market economy. These predictions collectively constitute hypothesis $2 \mathrm{D}$.

\section{Responses to Water-Damaging Accidents in the Czech Republic}

Using data on enforcement actions taken in response to water-damaging accidents in the Czech Republic from 1988 to 1992 , the subsequent empirical section tests these theoretical hypotheses concerning absolute and relative penalty use.

\section{A. Characterization of Economic Systems}

Using data from the Czech Republic to test these hypotheses is very appropriate because this country has experienced a stark change from a centrally planned economy to a market economy. At the time of communism's collapse in November 1989, the former Czechoslovakia was one of the

\footnotetext{
${ }^{8}$ The original hypotheses remain true if the effect of any change in the principal's objective is sufficiently small relative to the effect of the change in money's importance.
} 
Table 1.-Enforcement Responses To Water-Damaging Accidents, 1988-1992

\begin{tabular}{|c|c|c|c|c|c|c|c|}
\hline \multicolumn{8}{|c|}{ 1.a. Imposition of Individual Penalties } \\
\hline \multirow[b]{2}{*}{ Year } & \multirow[b]{2}{*}{ Accidents } & \multicolumn{3}{|c|}{ Monetary Fines } & \multicolumn{3}{|c|}{ Remediation Costs } \\
\hline & & No. & $\begin{array}{l}\text { Total Value } \\
\text { (1992 Kcs) }\end{array}$ & $\begin{array}{c}\text { Average Value } \\
\text { (1992 Kcs) }\end{array}$ & No. & $\begin{array}{l}\text { Total Value } \\
\text { (1992 Kcs) }\end{array}$ & $\begin{array}{c}\text { Average Value } \\
\text { (1992 Kcs) }\end{array}$ \\
\hline 1988 & 584 & 300 & $41,659,881$ & 138,866 & 44 & $9,276,627$ & 210,832 \\
\hline 1989 & 654 & 340 & $31,960,463$ & 94,001 & 361 & $26,244,884$ & 72,701 \\
\hline 1990 & 598 & 268 & $22,325,103$ & 83,303 & 170 & $12,077,124$ & 71,042 \\
\hline 1991 & 501 & 209 & $12,888,024$ & 61,665 & 43 & $9,449,791$ & 219,763 \\
\hline 1992 & 415 & 149 & $10,119,702$ & 67,917 & 41 & $19,661,021$ & 479,537 \\
\hline
\end{tabular}

Note: Czech Crowns deflated by Consumer Price Index for the Czech Republic [Source: Czech Statistical Office].

1.b. Combinations of Individual Penalties: Frequency of Penalty Package Selection

\begin{tabular}{ccccc} 
Year & Neither Penalty & Remediation Only & Monetary Fine Only & Both Penalties \\
\hline 1988 & 176 & 11 & 265 & 33 \\
1989 & 119 & 91 & 100 & 240 \\
1990 & 175 & 50 & 156 & 184 \\
1991 & 215 & 12 & 125 & 25 \\
1992 & 174 & 11 & 125 \\
\hline
\end{tabular}

Source: Czech Water Inspection.

most strict centrally planned economies in Central and Eastern Europe. As of 1986, the state sector generated 96.7\% of net material product (NMP) and the nonfarming private sector generated only $0.7 \%$ of NMP (Svejnar, 1995). Since communism's collapse, the Czech Republic has rapidly transformed itself towards a thriving capitalist economy as evidenced by the withering presence of state control over enterprises and prices, and by the emerging presence of private ownership and markets. In 1991, central planningthe system of production quotas and guaranteed sales-was abolished, $90 \%$ of all prices were deregulated, and smallscale privatization and restitution began (Svejnar, 1995). In 1992, transfers to the business sector in the state budget decreased, market institutions were introduced, and mass privatization began. By the end of 1992, most of the service industry was privately owned, and 50\% of construction activity was privately generated; nevertheless, only $14 \%$ of industrial production was privately generated (Svejnar, 1995).

Even though private ownership was still incomplete by 1992, the transitional market years of 1991 and 1992 represent an economic system that is dramatically different than the centrally planned system in place during 1988 to 1990. The empirical analysis accepts this division between economic systems mainly because 1990 is the last year when a "plan" was implemented.

\section{B. Legal Efforts to Protect Water Quality from Water-Damaging Accidents}

Using data on water enforcement to test the hypotheses is also appropriate because the Czech government has good reason to be concerned about its country's water quality and water-damaging accidents. In 1985 , only $17 \%$ of total surface water was classified as clean and as much as $22 \%$ was classified as extremely polluted. ${ }^{9}$ Moreover, waterdamaging accidents have significantly degraded water quality in the Czech Republic (Czech Ministry of the Environment, 1990). Table 1 shows the annual number of waterdamaging accidents from 1988 to 1992. Since the end of communist rule in 1989, the number of accidents has steadily declined. Certainly, the substantial decline in economic activity during this period-real GNP declined 20.7\% between 1989 and 1992-may explain much of this drop. Equally as plausible, monetary fines with real penalizing power may have begun to deter polluters from causing accidents.

Czech environmental authorities treat water-damaging accidents as potential violations of statutes banning the improper handling of substances harmful to water (1973 Water Act No. 138, hereafter the "Water Act," \$23-24). Once a water-damaging accident is detected, water authorities can impose remediation requirements and monetary fines, according to the Water Act (\$27) and the 1974 State Water Administration Act No. 130 (hereafter the "Water Administration Act," §24c). Although no general procedure for imposing remediation requirements exists, the Water Administration Act $(\$ 24 \mathrm{c})$ guides monetary fines according to several factors, including remediation costs. According to a Czech Water Inspection official, a firm's profitability and status in the privatization process also entered into monetary fine decisions during the capitalist transition (Půlpán, 1993). In particular, the official claims that the agency is "going easy" on privatizing firms with respect to monetary fines. Such behavior is consistent with the increasing effectiveness of monetary fines. Given that monetary fines had some penalizing power under central planning, as fines become

\footnotetext{
${ }^{9}$ Source: Czech Hydrometeorological Institute.
} 
more effective in the transitional market period, the agency optimally reduces their magnitude.

By law and in practice, water authorities can and do impose remediation and monetary fines simultaneously (Water Act, §27, 47). Table 1 presents a recent history of enforcement responses to water-damaging accidents. As shown, the annual number of accidents prompting a monetary fine has greatly decreased since 1988, even after taking into account the drop in accidents. More important, the average monetary fine imposed has dropped significantly. This decrease is in keeping with the Czech Water Inspection's purported policy of "going easy" on privatizing firms (reducing the size of monetary fines). In the case of remediation, the average cost imposed has greatly increased since 1989, even though the number of remediation requirements in 1991 and 1992 is only a fraction of what was demanded in 1989 and 1990. As a whole, remediation may have been applied evenly across the two economic periods. Collectively, these results seem to support the notion that monetary fines had some penalizing power in the centrally planned economy (case 1). However, hypothesis testing derived from multivariate analysis generates a different conclusion.

\section{Database on Water-Damaging Accidents}

Since 1988, the Czech Water Inspection-the main enforcer of Czech water protection laws-has maintained a database on individual water-damaging accidents, which includes penalties of required remediation costs (adjusted to 1992 levels), and monetary fine (adjusted to 1992 levels). The database also contains variables relevant to the Czech water authorities' decisions to impose penalties. Of these variables, this study utilizes the following:

1. type of water affected (for example, groundwater),

2. primary cause of the accident (for example, human error),

3. secondary cause of the accident, ${ }^{10}$

4. economic activity of the responsible party (for example, agriculture),

5. location of the accident by Czech Water Inspection region,

6. year of the accident;

7. measured damages caused by the accident (adjusted to 1992 levels); and

8. type of contaminant involved (for example, oil).

The year and location of the accident can be linked to the surface-water quality (represented by biological oxygen demand) of the Czech Water Inspection region affected by

\footnotetext{
${ }^{10}$ In some cases, two factors contribute to the cause of the accident. The Czech Water Inspection determines which factor is primary and which is secondary.
}

the accident. ${ }^{11}$ The year of the accident places each observation in an economic system. ${ }^{12}$ The Czech Water Inspection database contains a total of 2,710 accidents, and the Czech water authorities detected the responsible party in 2,298 of these cases. Because penalties cannot be imposed on unidentified polluters, these observations are dropped from the sample. (Complete data documentation is available upon request.)

\section{Econometric Analysis of Water-Damaging Accidents}

Using the described data, I formally test the hypotheses discussed above as they relate to the enforcement actions that were taken in response to water-damaging accidents in the Czech Republic.

\section{A. Structuring the Outcome Relationships and Estimation Techniques}

Econometric analysis estimates the decision process to impose penalties from three perspectives. The first decision perspective concerns the imposition of each penalty type separately, while ignoring penalty levels. This perspective proves useful if water authorities divide accidents into two categories-impose penalty or not impose-according to the costs and benefits of penalty imposition, while treating the need for each penalty type separately. This perspective permits the testing of hypotheses $1 \mathrm{~A}$ and $2 \mathrm{~A}$. The second decision perspective concerns the imposition of both penalties jointly by examining the selection of a penalty combination from four possibilities: neither penalty, remediation only, monetary fine only, and both penalties. This perspective proves useful if water authorities divide accidents into the four noted categories according to the costs and benefits of penalty imposition, while treating the need for penalties jointly. This perspective permits the testing of hypotheses $1 \mathrm{~B}, 1 \mathrm{D}, 2 \mathrm{~B}$, and 2D. The third decision perspective concerns the joint determination of the levels for required remediation costs and imposed monetary fines. This perspective permits the testing of hypotheses $1,1 \mathrm{C}, 2$, and $2 \mathrm{C}$.

In turn, I examine all three decision perspectives. For each perspective, I estimate two separate econometric models based on the sample time period. Model 1 uses data for 1988 to 1990 (the centrally planned economy), and model 2 uses data for 1991 to 1992 (the transitional market economy). The data is not pooled, because structural breaks in the three regression systems exist between the two economic systems. Estimates of the coefficients that are common to the two

\footnotetext{
${ }^{11}$ Although many parameters may represent surface-water quality, the most prominent parameter is biological oxygen demand, as it is reported in the Czech Water Inspection's yearbooks.

12 The database lacks some key explanatory variables - ownership of the enterprise (private or state), the profitability of the enterprise, and the organizational structure of the enterprise- that would be especially helpful to establish the efficacy of monetary fines.
} 
models, as a group, differ significantly between the economic systems for each decision perspective. ${ }^{13}$

Penalty Imposition-Each Penalty Type Treated Separately: Consider the first decision perspective which treats each penalty type separately. The regression system involves the following dependent variables:

$$
\begin{aligned}
r^{\delta} & =1 & & \text { if remediation is required, and } \\
& =0 & & \text { otherwise; and } \\
m^{\delta} & =1 & & \text { if a monetary fine is imposed, and } \\
& =0 & & \text { otherwise. }
\end{aligned}
$$

The independent variables include a constant, indicator variables for the primary causes (unknown/natural cause as benchmark), an indicator variable for the secondary cause ("not human error" as benchmark), measured damages, indicator variables for the economic activity of the responsible polluter (heavy industry as benchmark), an indicator variable for the type of water affected (surface water as benchmark), surface-water quality, and indicator variables for the type of contaminant ("other" contaminant as benchmark). Model 1 includes indicator variables for 1988 and 1989 (1990 as benchmark); model 2 includes an indicator variable for 1991 (1992 as benchmark). Define the complete set of independent variables as $Z .{ }^{14}$ The regression system is then structured as follows:

$$
\begin{aligned}
& r^{\delta}=a^{\prime} Z+e_{r}, \\
& m^{\delta}=c^{\prime} Z+e_{m},
\end{aligned}
$$

where $e_{r}$ and $e_{m}$ are the unobserved determinants for the required remediation equation and the monetary fine imposition equation, respectively. As one way of estimating the discrete choice of each penalty imposition, I make the probit (Maddala, 1983) assumptions and estimate the regression system with maximum-likelihood techniques. Estimation results are shown in table 2 .

\footnotetext{
${ }^{13}$ For the first decision perspective, the Wald test statistic for remediation is 107.95 , significant at the $1 \%$ level, and the Wald test statistic for monetary fines is 21.54, significant at the $15 \%$ level. (For analytical consistency, I choose to stretch the level of appropriate significance rather than to pool the data for this one equation.) For the second decision perspective, the Wald test statistic is 103.43 and significant at the $1 \%$ level. For the third decision perspective, the Wald test statistic for remediation costs is 61.56 , significant at the $1 \%$ level; the Wald test statistic for monetary fines is 27.15 , significant at the $10 \%$ level; and the Wald test statistic for the penalty level ratio is 26.82 , significant at the $5 \%$ level.

${ }^{14}$ In the case of monetary fines, the independent variables additionally include a zero-damage spline, which takes the value 1 when measured damages equal 0 , and the value 0 , otherwise. I omit the zero-damages

\begin{tabular}{|c|c|c|c|c|}
\hline \multirow[b]{2}{*}{ Variable } & \multicolumn{2}{|c|}{ Remediation Requirements } & \multicolumn{2}{|c|}{ Monetary Fines } \\
\hline & $\begin{array}{l}\text { Centrally } \\
\text { Planned }\end{array}$ & $\begin{array}{l}\text { Transitional } \\
\text { Market }\end{array}$ & $\begin{array}{l}\text { Centrally } \\
\text { Planned }\end{array}$ & $\begin{array}{c}\text { Transitional } \\
\text { Market }\end{array}$ \\
\hline Constant & $\begin{array}{c}-0.475^{* * *} \\
(0.215)\end{array}$ & $\begin{array}{c}-0.993 * * \\
(0.483)\end{array}$ & $\begin{array}{l}0.699 * * * \\
(0.220)\end{array}$ & $\begin{array}{c}0.313 \\
(0.371)\end{array}$ \\
\hline $\begin{array}{l}\text { Primary human } \\
\text { cause }^{1}\end{array}$ & $\begin{array}{l}0.381 * * * \\
(0.132)\end{array}$ & $\begin{array}{c}0.619^{*} \\
(0.362)\end{array}$ & $\begin{array}{c}0.125 \\
(0.110)\end{array}$ & $\begin{array}{c}0.089 \\
(0.193)\end{array}$ \\
\hline Other cause $^{1}$ & $\begin{array}{l}0.310 \\
(0.209)\end{array}$ & $\begin{array}{l}0.311 \\
(0.543)\end{array}$ & $\begin{array}{l}0.458 * * * \\
(0.178)\end{array}$ & $\begin{array}{r}-0.109 \\
(0.295)\end{array}$ \\
\hline Transport cause $^{1}$ & $\begin{array}{l}0.826^{* * * *} \\
(0.153)\end{array}$ & $\begin{array}{c}0.349 \\
(0.380)\end{array}$ & $\begin{array}{c}0.039 \\
(0.138)\end{array}$ & $\begin{array}{r}-0.085 \\
(0.206)\end{array}$ \\
\hline Technical cause $^{1}$ & $\begin{array}{l}0.658^{* * * *} \\
(0.137)\end{array}$ & $\begin{array}{l}0.686^{* * *} \\
(0.362)\end{array}$ & $\begin{array}{l}0.193^{*} \\
(0.120)\end{array}$ & $\begin{array}{l}0.195 \\
(0.197)\end{array}$ \\
\hline $\begin{array}{l}\text { Secondary } \\
\quad \text { human cause }^{2}\end{array}$ & $\begin{array}{l}0.131 \\
(0.102)\end{array}$ & $\begin{array}{c}-0.174 \\
(0.186)\end{array}$ & $\begin{array}{c}0.003 \\
(0.096)\end{array}$ & $\begin{array}{l}0.114 \\
(0.123)\end{array}$ \\
\hline $\begin{array}{l}\text { Measured dam- } \\
\text { ages (000's) }\end{array}$ & $\begin{array}{l}0.010^{* * * *} \\
(0.002)\end{array}$ & $\begin{array}{l}0.020 * * * \\
(0.004)\end{array}$ & $\begin{array}{c}0.002 \\
(0.002)\end{array}$ & $\begin{array}{l}0.006^{*} \\
(0.003)\end{array}$ \\
\hline $\begin{array}{l}\text { Zero-damages } \\
\text { spline }\end{array}$ & - & - & $\begin{array}{c}-0.378 \text { **** } \\
(0.094)\end{array}$ & $\begin{array}{c}-0.057 \\
(0.255)\end{array}$ \\
\hline 1988 or $1991^{3}$ & $\begin{array}{c}-0.966^{* * * *} \\
(0.107)\end{array}$ & $\begin{array}{c}0.047 \\
(0.144)\end{array}$ & $\begin{array}{l}0.227 * * * \\
(0.088)\end{array}$ & $\begin{array}{c}0.155 \\
(0.098)\end{array}$ \\
\hline $1989^{3}$ & $\begin{array}{l}0.752^{* * * *} \\
(0.084)\end{array}$ & & $\begin{array}{c}0.096 \\
(0.084)\end{array}$ & \\
\hline $\begin{array}{l}\text { Agricultural } \\
\text { activity }^{4}\end{array}$ & $\begin{array}{c}-0.223^{* *} \\
(0.104)\end{array}$ & $\begin{array}{c}-0.222 \\
(0.203)\end{array}$ & $\begin{array}{l}0.152 \\
(0.095)\end{array}$ & $\begin{array}{c}0.121 \\
(0.139)\end{array}$ \\
\hline $\begin{array}{l}\text { Other industrial } \\
\text { activity }^{4}\end{array}$ & $\begin{array}{c}-0.400 * * * * \\
(0.101)\end{array}$ & $\begin{array}{c}-0.461 * * * \\
(0.186)\end{array}$ & $\begin{array}{l}0.046 \\
(0.091)\end{array}$ & $\begin{array}{c}-0.213^{*} \\
(0.120)\end{array}$ \\
\hline Citizen activity ${ }^{4}$ & $\begin{array}{c}-1.400 * * * \\
(0.414)\end{array}$ & $\begin{array}{l}0.365 \\
(0.361)\end{array}$ & $\mathrm{a}$ & $\mathrm{a}$ \\
\hline $\begin{array}{l}\text { Military/foreign } \\
\text { activity }^{4}\end{array}$ & $\begin{array}{l}-1.007 * * * \\
(0.154)\end{array}$ & $\begin{array}{c}-0.261 \\
(0.290)\end{array}$ & $\begin{array}{l}-1.233 * * * \\
(0.139)\end{array}$ & $\begin{array}{l}-1.204 * * * \\
(0.221)\end{array}$ \\
\hline Groundwater ${ }^{5}$ & $\begin{array}{c}-0.009 \\
(0.082)\end{array}$ & $\begin{array}{l}0.244^{*} \\
(0.145)\end{array}$ & $\begin{array}{c}0.094 \\
(0.077)\end{array}$ & $\begin{array}{c}0.156^{*} \\
(0.097)\end{array}$ \\
\hline $\begin{array}{l}\text { Surface-water } \\
\text { quality }\end{array}$ & $\begin{array}{c}-0.094 * * \\
(0.040)\end{array}$ & $\begin{array}{c}-0.298 * * * \\
(0.083)\end{array}$ & $\begin{array}{c}-0.086^{* *} \\
(0.038)\end{array}$ & $\begin{array}{l}-0.162 * * * \\
(0.053)\end{array}$ \\
\hline Oil contaminant ${ }^{6}$ & $\begin{array}{l}0.253^{* * * *} \\
(0.101)\end{array}$ & $\begin{array}{c}0.221 \\
(0.210)\end{array}$ & $\begin{array}{c}0.081 \\
(0.091)\end{array}$ & $\begin{array}{l}0.207 \\
(0.133)\end{array}$ \\
\hline $\begin{array}{c}\text { Chemical con- } \\
\text { taminant }^{6}\end{array}$ & $\begin{array}{c}0.175 \\
(0.124)\end{array}$ & $\begin{array}{c}0.217 \\
(0.246)\end{array}$ & $\begin{array}{c}0.049 \\
(0.113)\end{array}$ & $\begin{array}{c}0.203 \\
(0.157)\end{array}$ \\
\hline $\begin{array}{l}\text { Number of } \\
\text { observations }\end{array}$ & 1,528 & 770 & 1,528 & 770 \\
\hline Log-likelihood & -748.865 & -186.310 & -910.147 & -477.136 \\
\hline
\end{tabular}
spline from the estimation of remediation requirements because the measurement of damages and the requirement of remediation are highly correlated.
}

Table 2.-Probit Estimation of Remediation Requirements and MONETARY FINES

Penalty Imposition-Penalty Types Treated Jointly: To model the second decision perspective (selection of a specific penalty combination), this paper employs discretechoice, random-utility theory (Ben-Akiva and Lerman, 1985). For each accident (indexed by $n$ ), the water authority chooses the penalty combination that yields the highest utility of all alternative combinations. Let $K$ denote the choice set of combinations: no penalty, only remediation, only monetary fines, and both penalties. Within this perspective, the probability of choosing combination $i$ is equal to the probability that the utility of combination $i, U_{i n}$, is greater than or equal to the utility of all other combinations in the choice set:

$$
\operatorname{Pr}(i \mid K)=\operatorname{Pr}\left[U_{i n} \geq U_{j n}, \forall j \in K\right] .
$$


In this random utility framework, overall utility, $U_{i n}$, is the sum of a deterministic component, $V_{i n}$, and a random component, $e_{i n}: U_{i n}=V_{i n}+e_{i n}$. If the random component is an identically and independently distributed (i.i.d.) type I extreme value with scale parameter $\mu$, the probability that the water authority in the case of accident $n$ chooses combination $i$ rather than combination $j$, denoted $\pi_{n}(i)$, takes the logit form as follows:

$$
\begin{gathered}
\pi_{n}(i)=P\left(V_{i n}+e_{i n} \geq V_{j n}+e_{j n}: \forall j \in K\right) \\
=\exp \left(\mu V_{i n}\right) / \sum_{j \in K} \exp \left(\mu V_{j n}\right) .
\end{gathered}
$$

Thus, estimation of the deterministic component, $V_{i n}$, permits the calculation of $\pi_{n}(i)$. I model $V_{i n}$ as an indirect utility function linearly conditional on $Z$, the explanatory variables, and $\beta$, the parameter vector: $V_{i n}=\beta^{\prime} Z$. I estimate this regression system using multinomial logit-estimation techniques. (Complete estimation results are available upon request from the author.)

Penalty Levels: Finally, consider the third decision perspective (determining levels of required remediation costs and imposed monetary fines). The dependent variables are

$$
\begin{aligned}
r & =\text { costs of remediation requirements, and } \\
m & =\text { monetary fine level. }
\end{aligned}
$$

Censoring affects both dependent variables. Required remediation costs are bottom-censored at zero: 1,689 of the 2,298 accidents prompted no remediation. According to the Water Administration Act (\$24), the monetary fine is bottomcensored at 10,000 Kcs and top-censored at 1,000,000 Kcs (both in nominal terms). Because the legal limit applies to nominal values, the inclusion of a top limit forces the analysis to estimate each individual year separately. Moreover, this inclusion fails to alter significantly the coefficient estimates. ${ }^{15}$ As further evidence, an examination of the data reveals that top censoring appears to be unimportant: the maximum monetary fine is imposed in only five cases. Consequently, the top-censoring problem is ignored. Also upon examination, the bottom-censoring problem for monetary fines actually occurs at $0 \mathrm{Kcs}$, not $10,000 \mathrm{Kcs} .{ }^{16}$ As one way of handling this complication, I make the Tobit (Maddala, 1983) assumptions and estimate the regression system with maximum-likelihood techniques. Estimation results are shown in table 3.

To test the modified hypotheses concerning relative penalty use, econometric analysis estimates the ratio of

\footnotetext{
${ }^{15}$ Wald test statistics for the years 1988-1992 are 0.008, 0.001, 0.186, 0.057 , and 0.002 , respectively, and significant only at levels greater than $10 \%$.

${ }^{16}$ Of course, I cannot rule out the possibility that a certain percentage of the accidents are bottom-censored at $10,000 \mathrm{Kcs}$ and the remaining accidents are not.
}

penalty levels. First, the analysis constructs the ratio of required remediation cost levels to total penalty levels: $r /(r+m)$. This construction allows calculation of a ratio even when only one penalty type is imposed. Second, the analysis restricts the sample to accidents prompting the imposition of at least one penalty type. Otherwise, the constructed ratio is undefined, because $r+m=0$. The ratio varies between 0 and 1 and censoring affects the ratio at both end values. As one way of handling this complication, I make the two-limit Tobit [Maddala (1983)] assumptions and estimate the ratio with maximum likelihood techniques. Estimation results are shown in Table 4.

\section{B. Hypothesis Testing}

To test the hypotheses, the analysis calculates and compares the predicted values of the dependent variables for the two economic systems. For the imposition of each penalty type and the selection of a particular penalty combination, the predicted values apply to the probability of imposition and selection, respectively. For the levels of each penalty type and the ratio of penalty levels, the predicted values apply to levels and the ratio, respectively. To facilitate the comparison of economic systems, let CPE denote the centrally planned period (1988-1990) and MKT denote the transitional market period (1991-1992). To calculate the predicted values, the analysis evaluates the explanatory variables at their sample means for each separate economic system, denoted $X^{\mathrm{CPE}}$ and $X^{\mathrm{MKT}} \cdot{ }^{17}$ For each dependent variable, the difference between the predicted value for one economic system and the predicted value for the other system measures the emphasis of penalty use in one system relative to the other. In turn, this subsection calculates and evaluates these differences for the three decision perspectives: imposition of each penalty type treated separately, selection of a penalty combination, and determination of penalty levels, including their ratio.

Imposition of Each Penalty Type Treated Separately: Consider the first decision perspective. Define the following predicted probabilities of penalty imposition in economic system $j$, evaluated at $X^{j}$, where $j \in\{\mathrm{CPE}, \mathrm{MKT}\}$ :

$$
\begin{aligned}
P_{r}^{j}\left(X^{j}\right)= & \text { predited probability of imposing remediation } \\
& \text { requirement in economic system } j, \text { and } \\
P_{m}^{j}\left(X^{j}\right)= & \text { predicted probability of imposing a monetary } \\
& \text { fine in economic system } j .
\end{aligned}
$$

For each penalty type, then define the difference between the predicted probability of imposition in the MKT system and

\footnotetext{
17 The sample mean for the entire period of analysis (1988-1992) is not considered for evaluation because structural breaks between the two economic systems appear in each regression system.
} 
OPTIMAL MIX OF PENALTY TYPES BETWEEN TWO ECONOMIC SYSTEMS

Table 3.-Tobit Estimation of Required Remediation Costs and Monetary Fine Levels

\begin{tabular}{|c|c|c|c|c|}
\hline \multirow[b]{2}{*}{ Variable } & \multicolumn{2}{|c|}{ Required Remediation Costs } & \multicolumn{2}{|c|}{ Monetary Fine Levels } \\
\hline & $\begin{array}{l}\text { Centrally } \\
\text { Planned }\end{array}$ & $\begin{array}{c}\text { Transitional } \\
\text { Market }\end{array}$ & $\begin{array}{l}\text { Centrally } \\
\text { Planned }\end{array}$ & $\begin{array}{c}\text { Transitional } \\
\text { Market }\end{array}$ \\
\hline Constant & $\begin{array}{c}-267,240 * * * \\
(78,570)\end{array}$ & $\begin{array}{c}-958,010 * * \\
(406,000)\end{array}$ & $\begin{array}{l}-1,251 \\
(41,027)\end{array}$ & $\begin{array}{c}63,133 * \\
(38,067)\end{array}$ \\
\hline Primary human cause ${ }^{1}$ & $\begin{array}{l}103,070 * * \\
(49,350)\end{array}$ & $\begin{array}{l}753,200 * * * \\
(307,500)\end{array}$ & $\begin{array}{r}-30,806 \\
(21,316)\end{array}$ & $\begin{array}{l}-1,001 \\
(21,265)\end{array}$ \\
\hline Other cause $^{1}$ & $\begin{array}{l}75,409 \\
(77,110)\end{array}$ & $\begin{array}{c}479,800 \\
(411,400)\end{array}$ & $\begin{array}{l}-111,549 \text { **** } \\
(36,944)\end{array}$ & $\begin{array}{c}-27,415 \\
(33,358)\end{array}$ \\
\hline Transport cause $^{1}$ & $\begin{array}{l}224,430 * * * \\
(56,320)\end{array}$ & $\begin{array}{c}429,110 \\
(316,100)\end{array}$ & $\begin{array}{c}-46,441^{*} \\
(26,988)\end{array}$ & $\begin{array}{c}-33,973 \\
(22,960)\end{array}$ \\
\hline Technical cause ${ }^{1}$ & $\begin{array}{l}214,720 * * * \\
(50,680)\end{array}$ & $\begin{array}{l}638,500 * * \\
(308,200)\end{array}$ & $\begin{array}{c}3,752 \\
(22,882)\end{array}$ & $\begin{array}{c}8,009 \\
(21,596)\end{array}$ \\
\hline Secondary human cause ${ }^{2}$ & $\begin{array}{c}27,961 \\
(36,470)\end{array}$ & $\begin{array}{c}-281,990^{* *} \\
(143,700)\end{array}$ & $\begin{array}{c}28,742^{*} \\
(17,878)\end{array}$ & $\begin{array}{c}21,174 \\
(13,334)\end{array}$ \\
\hline Measured damages & $\begin{array}{l}1.630 * * * \\
(0.077)\end{array}$ & $\begin{array}{l}4.359 * * * \\
(0.538)\end{array}$ & $\begin{array}{l}0.126 * * * \\
(0.045)\end{array}$ & $\begin{array}{c}0.091 \\
(0.082)\end{array}$ \\
\hline Zero-damages spline & - & - & $\begin{array}{c}-34,036^{* *} \\
(16,762)\end{array}$ & $\begin{array}{c}-63,004 * * * \\
(22,158)\end{array}$ \\
\hline 1988 or $1991^{3}$ & $\begin{array}{c}-263,360 * * * \\
(41,350)\end{array}$ & $\begin{array}{l}-17,956 \\
(110,000)\end{array}$ & $\begin{array}{l}69,095 * * * \\
(17,023)\end{array}$ & $\begin{array}{c}10,962 \\
(10,669)\end{array}$ \\
\hline $1989^{3}$ & $\begin{array}{l}162,160 * * * \\
(30,540)\end{array}$ & & $\begin{array}{c}22,389 \\
(16,274)\end{array}$ & \\
\hline Agricultural activity ${ }^{4}$ & $\begin{array}{c}-110,980 * * * \\
(37,360)\end{array}$ & $\begin{array}{r}-250,270 \\
(157,200)\end{array}$ & $\begin{array}{c}-19,182 \\
(17,931)\end{array}$ & $\begin{array}{r}-11,165 \\
(14,662)\end{array}$ \\
\hline Other industrial activity ${ }^{4}$ & $\begin{array}{c}-146,410 * * * \\
(36,000)\end{array}$ & $\begin{array}{c}-445,030 * * * \\
(146,500)\end{array}$ & $\begin{array}{c}-43,334 * * * \\
(17,397)\end{array}$ & $\begin{array}{c}-35,221 * * * \\
(13,102)\end{array}$ \\
\hline Citizen activity $^{4}$ & $\begin{array}{c}-452,640 * * * \\
(164,900)\end{array}$ & $\begin{array}{c}206,170 \\
(279,800)\end{array}$ & $\begin{array}{l}-1,359,607 \\
(14,888,333)\end{array}$ & $\begin{array}{c}-717,622 \\
(8,506,090)\end{array}$ \\
\hline Military/foreign activity & $\begin{array}{c}-309,010 * * * \\
(57,540)\end{array}$ & $\begin{array}{l}-55,287 \\
(203,200)\end{array}$ & $\begin{array}{c}-253,014 * * * \\
(30,509)\end{array}$ & $\begin{array}{c}-117,707 * * * \\
(25,147)\end{array}$ \\
\hline Groundwater ${ }^{5}$ & $\begin{array}{l}48,609 * \\
(29,180)\end{array}$ & $\begin{array}{l}237,900 * * \\
(112,600)\end{array}$ & $\begin{array}{c}8,759 \\
(14,545)\end{array}$ & $\begin{array}{c}16,912 * \\
(10,558)\end{array}$ \\
\hline Surface-water quality & $\begin{array}{r}-26,589^{*} \\
(14,280)\end{array}$ & $\begin{array}{c}-228,850 * * * \\
(65,380)\end{array}$ & $\begin{array}{c}6,305 \\
(7,110)\end{array}$ & $\begin{array}{r}-10,492 * \\
(5,742)\end{array}$ \\
\hline Oil contaminant ${ }^{6}$ & $\begin{array}{c}48,861 \\
(36,650)\end{array}$ & $\begin{array}{c}233,390 \\
(167,200)\end{array}$ & $\begin{array}{c}16,375 \\
(17,547)\end{array}$ & $\begin{array}{c}23,177 * \\
(14,438)\end{array}$ \\
\hline Chemical contaminant $^{6}$ & 52,839 & 266,990 & 15,556 & 14,233 \\
\hline & $(44,420)$ & $(190,800)$ & $(21,683)$ & $(17,014)$ \\
\hline Number of observations & 1,528 & 770 & 1,528 & 770 \\
\hline Normal standard deviation & 399,160 & 811,750 & 230,648 & 123,264 \\
\hline Log-likelihood & $-8,013$ & $-1,204$ & $-12,833$ & $-4,920$ \\
\hline
\end{tabular}

the predicted probability in the CPE system, both evaluated at $X^{j}$, as follows:

$$
\begin{aligned}
& \Delta P_{r}\left(X^{j}\right)=P_{r}^{\mathrm{MKT}}\left(X^{j}\right)-P_{r}^{\mathrm{CPE}}\left(X^{j}\right) \\
& \quad \text { and } \Delta P_{m}\left(X^{j}\right)=P_{m}^{\mathrm{MKT}}\left(X^{j}\right)-P_{m}^{\mathrm{CPE}}\left(X^{j}\right)
\end{aligned}
$$

As constructed, these differences measure the emphasis placed on each penalty type in the transitional market period relative to the centrally planned period. According to these estimated measures, as shown in table 5a, water authorities significantly emphasized remediation under central planning and monetary fines in the transitional market period consistent with hypothesis $2 \mathrm{~A}$.

This first decision perspective does not allow the testing of relative penalty use because it ignores potential overlap of the two imposition decisions. To overcome this problem, the analysis turns to the second decision perspective involving the selection of a penalty combination, which accommodates this overlapping of penalty imposition.

Selection of Penalty Combination: Consider the second decision perspective. First, examine the selection of various penalty combinations relative to the imposition of "neither penalty." Define the following predicted probabilities of selecting a particular penalty combination relative to neither penalty in economic system $j$, evaluated at $X^{j}$, where $j \in$ $\{\mathrm{CPE}, \mathrm{MKT}\}$ :

$$
\begin{aligned}
P_{r o}^{j}\left(X^{j}\right)= & \text { predicted probability of selecting a } \\
& \text { combination involving remediation only } \\
& \text { relative to imposing neither penalty } \\
& \text { in economic system } j,
\end{aligned}
$$




\begin{tabular}{|c|c|c|}
\hline Variable & $\begin{array}{l}\text { Centrally } \\
\text { Planned }\end{array}$ & $\begin{array}{l}\text { Transitional } \\
\text { Market }\end{array}$ \\
\hline Constant & $\begin{array}{l}0.877 * * * \\
(0.149)\end{array}$ & $\begin{array}{c}0.840 \\
(0.525)\end{array}$ \\
\hline Human cause $^{1}$ & $\begin{array}{c}0.112 \\
(0.088)\end{array}$ & $\begin{array}{c}0.439 \\
(0.359)\end{array}$ \\
\hline Other cause $^{1}$ & $\begin{array}{l}0.584 * * * \\
(0.142)\end{array}$ & $\begin{array}{c}0.454 \\
(0.524)\end{array}$ \\
\hline Transport cause $^{1}$ & $\begin{array}{l}0.219 * * \\
(0.104)\end{array}$ & $\begin{array}{c}0.297 \\
(0.381)\end{array}$ \\
\hline Technical cause $^{1}$ & $\begin{array}{c}0.120 \\
(0.091)\end{array}$ & $\begin{array}{c}0.320 \\
(0.354)\end{array}$ \\
\hline Secondary human cause ${ }^{2}$ & $\begin{array}{l}0.008 \\
(0.064)\end{array}$ & $\begin{array}{r}-0.129 \\
(0.180)\end{array}$ \\
\hline Measured damages & $\begin{array}{c}-0.0000007 * * * \\
(0.0000002)\end{array}$ & $\begin{array}{r}-0.000002^{* *} \\
(0.0000007)\end{array}$ \\
\hline Zero-damages spline & $\begin{array}{l}-0.848 * * * \\
(0.060)\end{array}$ & $\begin{array}{l}-1.822 * * * \\
(0.240)\end{array}$ \\
\hline 1988 or $1991^{3}$ & $\begin{array}{c}-0.458 * * * \\
(0.077)\end{array}$ & $\begin{array}{c}-0.020 \\
(0.142)\end{array}$ \\
\hline $1989^{3}$ & $\begin{array}{l}0.203^{* * * *} \\
(0.055)\end{array}$ & \\
\hline Agricultural activity ${ }^{4}$ & $\begin{array}{c}-0.249 * * * \\
(0.066)\end{array}$ & $\begin{array}{r}-0.154 \\
(0.191)\end{array}$ \\
\hline Other industrial activity ${ }^{4}$ & $\begin{array}{l}-0.189 * * * \\
(0.063)\end{array}$ & $\begin{array}{r}-0.339^{*} \\
(0.190)\end{array}$ \\
\hline Citizen activity ${ }^{4}$ & $\begin{array}{c}3.914 \\
(140.8)\end{array}$ & $\begin{array}{l}6.195 \\
(127.0)\end{array}$ \\
\hline Military/foreign activity ${ }^{4}$ & $\begin{array}{l}0.264^{* *} \\
(0.123)\end{array}$ & $\begin{array}{l}0.747 \text { *** } \\
(0.289)\end{array}$ \\
\hline Groundwater $^{5}$ & $\begin{array}{c}-0.006 \\
(0.052)\end{array}$ & $\begin{array}{c}0.142 \\
(0.145)\end{array}$ \\
\hline Surface-water quality & $\begin{array}{c}-0.076^{* * * *} \\
(0.026)\end{array}$ & $\begin{array}{c}-0.144^{*} \\
(0.085)\end{array}$ \\
\hline Oil contaminant ${ }^{6}$ & $\begin{array}{c}-0.096 \\
(0.066)\end{array}$ & $\begin{array}{c}0.203 \\
(0.208)\end{array}$ \\
\hline Chemical contaminant ${ }^{6}$ & $\begin{array}{l}-0.231 * * * \\
(0.082)\end{array}$ & $\begin{array}{c}0.278 \\
(0.238)\end{array}$ \\
\hline Number of observations & 1,058 & 381 \\
\hline Normal standard deviation & 0.629 & 0.803 \\
\hline Log-likelihood & -713.178 & -136.578 \\
\hline
\end{tabular}

Standard errors noted inside parentheses.

$*, * *, * * *$ indicate statistical differences from zero at significance levels $0.10,0.05$, and 0.01 respectively.

Omitted indicator categories: $1=$ Unknown/Natural Causes; $2=$ Not Human Error; $3=1990$ or 1992; $4=$ Heavy Industry; 5 = Surface Water; $6=$ Other Contaminant.

$$
\begin{aligned}
P_{m o}^{j}\left(X^{j}\right)= & \text { predicted probability of selecting a } \\
& \text { combination involving a monetary fine only } \\
& \text { relative to imposing neither penalty } \\
& \text { in economic system } j, \text { and }
\end{aligned}
$$$$
P_{b}^{j}\left(X^{j}\right)=\text { predicted probability of selecting a }
$$$$
\text { combination involving both penalties relative }
$$$$
\text { to imposing neither penalty in economic }
$$$$
\text { system } j \text {. }
$$

For each penalty combination, then define the difference between the predicted probability of selection in the MKT system and the predicted probability in the CPE system, both evaluated at $X^{j}$ :

$$
\Delta P_{r o}\left(X^{j}\right)=P_{r o}^{\mathrm{MKT}}\left(X^{j}\right)-P_{r}^{\mathrm{CPE}}\left(X^{j}\right),
$$

$$
\begin{aligned}
& \Delta P_{m o}\left(X^{j}\right)=P_{m o}^{\mathrm{MKT}}\left(X^{j}\right)-P_{m o}^{\mathrm{CPE}}\left(X^{j}\right), \text { and } \\
& \Delta P_{b}\left(X^{j}\right)=P_{b}^{\mathrm{MKT}}\left(X^{j}\right)-P_{b}^{\mathrm{CPE}}\left(X^{j}\right),
\end{aligned}
$$

where $j \in\{\mathrm{CPE}, \mathrm{MKT}\}$. As constructed, these differences measure the emphasis placed on each penalty combination (relative to no penalty) in the transitional market period relative to the centrally planned period. According to these estimated measures, as shown in table 5b(i), water authorities significantly emphasized the sole use of remediation under central planning, consistent with hypothesis $2 \mathrm{~B}$. In addition, water authorities significantly emphasized the sole use of monetary fines and the joint use of both penalties in the centrally planned period, inconsistent with hypotheses $1 \mathrm{~B}$ and $2 \mathrm{~B}$. These last results strengthen the need to test the hypotheses of relative penalty use.

To test the relative use of remediation requirements and monetary fines, consider the selection of various penalty combinations relative to the imposition of remediation only or a monetary fine only. Define the following predicted probabilities of selecting a particular penalty combination relative to an alternative combination in economic system $j$, evaluated at $X^{j}$, where $j \in\{\mathrm{CPE}, \mathrm{MKT}\}$ :

$$
\begin{aligned}
{\left[P_{b} / P_{r o}\right]^{j}\left(X^{j}\right)=} & \text { predicted probability of selecting } \\
& \text { a combination involving both } \\
& \text { penalties relative to remediation } \\
& \text { only in economic system } j, \\
{\left[P_{b} / P_{m o}\right]^{j}\left(X^{j}\right)=} & \text { predicted probability of selecting a } \\
& \text { combination involving both } \\
& \text { penalties relative to a monetary fine } \\
& \text { only in economic system } j, \text { and } \\
{\left[P_{r o} / P_{m o}\right]^{j}\left(X^{j}\right)=} & \text { predicted probability of selecting a } \\
& \text { combination involving remediation } \\
& \text { relative to a monetary fine only in } \\
& \text { economic system } j .
\end{aligned}
$$

For each penalty combination, then define the difference between the predicted probability of selection in the MKT system and the predicted probability in the CPE system, both evaluated at $X^{j}$ :

$$
\begin{aligned}
& \Delta\left[P_{b} / P_{r o}\right]\left(X^{\mathrm{CPE}}\right)=\left[P_{b} / P_{r o}\right]^{\mathrm{MKT}}\left(X^{j}\right)-\left[P_{b} / P_{r o}\right]^{\mathrm{CPE}}\left(X^{j}\right), \\
& \Delta\left[P_{b} / P_{m o}\right]\left(X^{\mathrm{CPE}}\right)=\left[P_{b} / P_{m o}\right]^{\mathrm{MKT}}\left(X^{j}\right)-\left[P_{b} / P_{m o}\right]^{\mathrm{CPE}}\left(X^{j}\right), \text { and } \\
& \Delta\left[P_{r o} / P_{m o}\left[\left(X^{\mathrm{CPE}}\right)=\left[P_{r o} / P_{m o}\right]^{\mathrm{MKT}}\left(X^{j}\right)-\left[P_{r o} / P_{m o}\right]^{\mathrm{CPE}}\left(X^{j}\right) .\right.\right.
\end{aligned}
$$

As constructed, these differences measure the emphasis placed on each penalty combination (relative to remediation 
TABLE 5.-Hypothesis Testing

\begin{tabular}{|c|c|c|c|}
\hline \multicolumn{4}{|l|}{ 5a. Penalty Imposition } \\
\hline \multirow{2}{*}{$\begin{array}{c}\text { Emphasis in } \\
\text { Transitional } \\
\text { Market Relative } \\
\text { to CPE }\end{array}$} & \multirow[b]{2}{*}{$\begin{array}{l}\text { Estimated } \\
\text { Magnitude }\end{array}$} & \multicolumn{2}{|c|}{$\begin{array}{l}\text { Consistency with } \\
\text { Hypotheses and Significance }\end{array}$} \\
\hline & & $\begin{array}{l}\text { Hypothesis } \\
1 \mathrm{~A}\end{array}$ & $\begin{array}{c}\text { Hypothesis } \\
2 \mathrm{~A}\end{array}$ \\
\hline \multicolumn{4}{|c|}{ Mean Values for Centrally Planned Period (1988-1990) } \\
\hline $\begin{array}{l}\text { Remediation emphasis } \\
\text { Monetary fine emphasis }\end{array}$ & $\begin{array}{l}\Delta P_{r}\left(X^{\mathrm{CPE}}\right)=-1.04 \\
\Delta P_{m}\left(X^{\mathrm{CPE}}\right)=0.403\end{array}$ & $\begin{array}{l}\text { No } \\
\text { No }\end{array}$ & $\begin{array}{l}\text { Yes }-1 \% \\
\text { Yes }-1 \%\end{array}$ \\
\hline \multicolumn{4}{|c|}{ Mean Values for Transitional Market Period (1991-1992) } \\
\hline $\begin{array}{l}\text { Remediation emphasis } \\
\text { Monetary fine emphasis }\end{array}$ & $\begin{array}{l}\Delta P_{r}\left(X^{\mathrm{MKT}}\right)=-1.04 \\
\Delta P_{m}\left(X^{\mathrm{MKT}}\right)=0.322\end{array}$ & $\begin{array}{l}\text { No } \\
\text { No }\end{array}$ & $\begin{array}{l}\text { Yes }-1 \% \\
\text { Yes-1\% }\end{array}$ \\
\hline \multicolumn{4}{|c|}{$\begin{array}{l}\text { 5b. Selection of Penalty Combination } \\
\text { 5b(i). Absolute Probabilities }\end{array}$} \\
\hline $\begin{array}{l}\text { Emphasis in } \\
\text { Transitional }\end{array}$ & & \multicolumn{2}{|c|}{$\begin{array}{l}\text { Consistency with } \\
\text { Hypotheses and Significance }\end{array}$} \\
\hline $\begin{array}{c}\text { Market Relative } \\
\text { to CPE }\end{array}$ & $\begin{array}{l}\text { Estimated } \\
\text { Magnitude }\end{array}$ & $\begin{array}{c}\text { Hypothesis } \\
\text { 1B }\end{array}$ & $\begin{array}{c}\text { Hypothesis } \\
\text { 2B }\end{array}$ \\
\hline
\end{tabular}

Mean Values for Centrally Planned Period (1988-1990)

Remediation only emphasis

Monetary fine only emphasis

Both penalties emphasis $\begin{array}{lll}\Delta P_{r o}\left(X^{\mathrm{CPE}}\right)=-2.587 & \text { No } & \text { Yes- } 1 \% \\ \Delta P_{m o}\left(X^{\mathrm{CPE}}\right)=-0.930 & \text { No } & \text { No } \\ \Delta P_{b}\left(X^{\mathrm{CPE}}\right)=-2.753 & \text { No } & \text { No }\end{array}$

Mean Values for Transitional Market Period (1991-1992)

Remediation only emphasis

Monetary fine only emphasis

Both penalties emphasis $\Delta P_{r o}\left(X^{\mathrm{MKT}}\right)=-2.450 \quad$ No $\quad$ Yes $-1 \%$ $\Delta P_{m o}\left(X^{\mathrm{MKT}}\right)=-0.547 \quad$ No $\quad$ No Wald test statisic order.

5b. Selection of Penalty Combination

5b(ii). Relative Probabilities

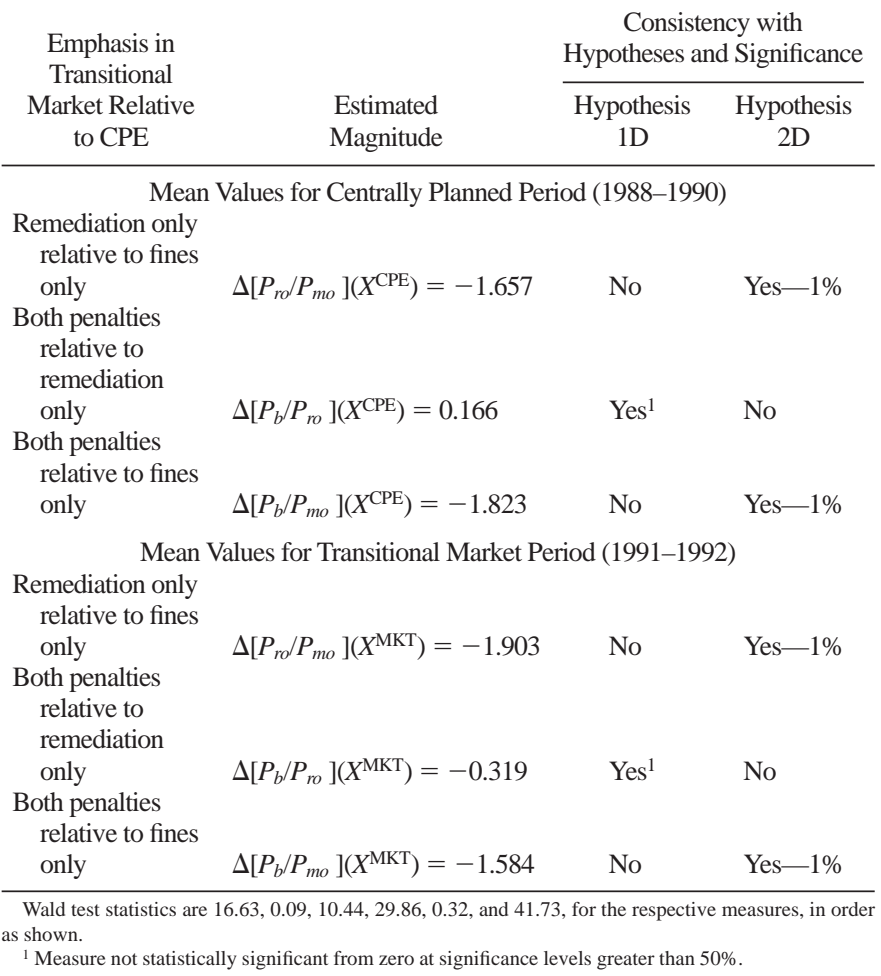

TABLE 5.-(CONTINUED)

\begin{tabular}{|c|c|c|c|}
\hline \multicolumn{4}{|c|}{ 5c. Penalty Levels: Individual and Ratio } \\
\hline \multirow{3}{*}{$\begin{array}{c}\text { Emphasis in } \\
\text { Transitional } \\
\text { Market Relative } \\
\text { to CPE }\end{array}$} & \multirow{3}{*}{$\begin{array}{l}\text { Estimated } \\
\text { Magnitude }\end{array}$} & \multicolumn{2}{|c|}{$\begin{array}{c}\text { Consistency with } \\
\text { Hypotheses and Significance }\end{array}$} \\
\hline & & Hypothesis & Hypothesis \\
\hline & & 1 or $1 \mathrm{C}$ & 2 or $2 \mathrm{C}$ \\
\hline
\end{tabular}

Mean Values for Centrally Planned Period (1988-1990)

Remediation costs $\quad \Delta r\left(X^{\mathrm{CPE}}\right)=-1,014,310 \quad$ No $\quad$ Yes-1\%

Monetary fine

levels

$\Delta m\left(X^{\mathrm{CPE}}\right)=-3,026 \quad$ No $\quad$ No

Remediation costs

relative to fine

levels

$\Delta y\left(X^{\mathrm{CPE}}\right)=-0.432$

No $\quad$ Yes- $1 \%$

Mean Values for Transitional Market Period (1991-1992)

Remediation costs $\Delta r\left(X^{\mathrm{MKT}}\right)=-941,601$

$\begin{array}{llll}\text { Monetary fines } & \Delta m\left(X^{\mathrm{MKT}}\right)=-10,953 & \text { No } & \text { No }\end{array}$

Remediation costs

relative to fine

levels

$\Delta y\left(X^{\mathrm{MKT}}\right)=-0.530$

No $\quad$ Yes-1\%

Wald test statistics are $44.89,0.0001,15.27,49.18,0.001$, and 23.81 , for the respective measures, in order as shown.

only or monetary fine only) in the transitional market period relative to the centrally planned period. According to these estimated measures, as shown in table $5 \mathrm{~b}$ (ii), water authorities emphasized the use of both penalties relative to the use of remediation only (that is, imposition of monetary fines, conditional on a remediation requirement) in neither period, consistent with hypothesis 1D. In addition, under central planning, water authorities significantly emphasized the use of both penalties relative to the use of monetary fines only (that is, imposition of remediation, conditional on monetary fine imposition) and the use of remediation only relative to the use of monetary fines only (that is, imposition of remediation, conditional on the imposition of at least one penalty type), consistent with hypothesis 2D.

Penalty Levels: Finally, consider the third decision perspective regarding penalty levels. Define the following predicted penalty levels for economic system $j$, evaluated at $X^{j}$, where $j \in\{\mathrm{CPE}, \mathrm{MKT}\}$ :

$$
\begin{aligned}
r^{j}\left(X^{j}\right)= & \text { predicted level of medication costs for } \\
& \text { economic system } j, \text { and } \\
m^{j}\left(X^{j}\right)= & \text { predicted level of monetary fines for } \\
& \text { economic system } j .
\end{aligned}
$$

For each penalty type, define the difference between the predicted level in the MKT system and the predicted level in the CPE system, evaluated at $X^{j}$, where $j \in\{\mathrm{CPE}, \mathrm{MKT}\}$ :

$$
\begin{aligned}
& \Delta r\left(X^{j}\right)=r^{\mathrm{MKT}}\left(X^{j}\right)-r^{\mathrm{CPE}}\left(X^{j}\right) \\
& \quad \text { and } \Delta m\left(X^{j}\right)=m^{\mathrm{MKT}}\left(X^{j}\right)-m^{\mathrm{CPE}}\left(X^{j}\right) .
\end{aligned}
$$

As constructed, these differences measure the emphasis placed on each penalty type in the transitional market period 
relative to the centrally planned period. According to these estimated measures, as shown in table $5 \mathrm{c}$, water authorities significantly emphasized remediation costs under central planning, consistent with hypothesis 2 . In addition, water authorities emphasized monetary fines in neither period, inconsistent with hypotheses 1 and 2. This inconclusive result strengthens the need to examine relative penalty use by estimating the penalty level ratio.

Estimation of this ratio permits the testing of the modified hypotheses concerning relative use of penalties. Let $y$ represent the ratio of remediation costs and total penalty levels: $y=r /(r+m)$. Define the difference between the predicted ratio in the MKT period and CPE period as follows:

$$
\Delta y\left(X^{j}\right)=y^{\mathrm{MKT}}\left(X^{j}\right)-y^{\mathrm{CPE}}\left(X^{j}\right), \text { where } j \in\{\mathrm{CPE}, \mathrm{MKT}\} .
$$

This difference measures the emphasis placed on remediation costs as compared to monetary fines in the transitional market period relative to the centrally planned period. As shown in table 5c, water authorities significantly emphasized remediation costs under central planning and monetary fines during the capitalist transition, consistent with hypothesis $2 \mathrm{C}$.

\section{Interpretation of Empirical Results}

Collectively, only one result weakly supports the notion that monetary fines had some penalizing power under central planning (case 1) and nearly all reject this notion. Instead, these results mostly support the notion that monetary fines had no penalizing power under central planning (case 2). The most-convincing results involve the use of remediation requirements, especially the emphasis of remediation cost levels as compared to monetary fine levels under central planning relative to the capitalist transition. This conclusion is consistent with reports on the Czech Republic. According to World Bank (1992), fines "when accompanied by soft budget policies, had no impact on polluters' behavior." According to Czech Ministry of the Environment (1990), enterprises' annual subsidies often included funds earmarked to pay monetary fines: "payments [fines] had been incorporated into the [production] costs and [product] prices." 18

If monetary fines lacked penalizing power under central planning, why did Czech water authorities impose them at all? Without any effect on polluters' behavior, Czech water authorities could have imposed monetary fines to display their environmental consciousness to the Czech citizenry and to Western countries without experiencing any social costs beyond imposition costs, the practice noted as "show" in Section IIB. ${ }^{19}$

\footnotetext{
${ }^{18}$ Peterson (1993) documents the neutralization of monetary fines by subsidies in the Soviet case.

${ }^{19}$ Peterson (1993) supports the view that protection agencies under central planning knowingly assigned ineffective monetary fines and more
}

Modification of the hypotheses to examine the relative use of penalties proves justified. Water authorities unambiguously emphasized the absolute use of remediation in terms of both levels and imposition during the centrally planned period and the absolute imposition of monetary fines in the transitional market period. However, authorities also emphasized the sole use of monetary fines and the joint use of both penalties during the centrally planned period. (The emphasis of monetary fines in terms of levels in this period is statistically insignificant. ${ }^{20}$ ) These collective results possibly indicate a shift in the authorities' objective towards a greater concern for enterprises' financial situations and/or a lesser desire for "show" in the transitional market period. Contrary to conventional wisdom, these results mostly reject the notion of greater environmental awareness expressed in stronger enforcement. By examining the relative use of penalties, the results unambiguously support the relative emphasis of remediation in the centrally planned period as predicted under case 2 .

\section{Summary}

This paper uses principal-agent theory to analyze the optimal mix of monetary- and resource-based penalties in two economic systems: a centrally planned economy and a market economy. Principal-agent theory generates two sets of testable hypotheses concerning the use of each penalty type in each economic system. One set concerns the absolute use of penalty types, which is appropriate when the principal's objective is sufficiently constant across the two economic systems. The other set concerns the relative use of penalty types, which is appropriate when the principal's objective differs sufficiently between the two economic systems. This paper tests these hypotheses using data on the enforcement of water-protection laws in the Czech Republic regarding penalty responses to water-damaging accidents from 1988 to 1992.

Estimation of enforcement responses follows three different decision perspectives: imposition of each penalty type, selection of a penalty combination, and level of each penalty type.

Based on the collective results, examining the relative use of penalties appears justified. Moreover, the collective results reject the notion that monetary fines had some penalizing power under central planning, yet they strongly support the notion that monetary fines had no penalizing power under central planning. If monetary fines had no penalizing power under central planning, then why did water authorities impose them at all? Possibly, the Czech water authorities used monetary fines for show.

\footnotetext{
generally describes the symbolic nature of environmental protection actions in Soviet-type economies.

${ }^{20}$ This result may stem from a seemingly random determination of fine
} levels based mostly on political purposes in the centrally planned period. 


\section{REFERENCES}

Ben-Akiva, Mosha, and Steve Lerman, Discrete-Choice Analysis: Theory and Application to Travel Demand (Cambridge, MA: MIT Press, 1985).

Cohen, Mark, "Optimal Enforcement Strategy to Prevent Oil Spills: An Application of a Principal-Agent Model with Moral Hazard," Journal of Law and Economics 30:1 (1987), 23-51.

Czech Ministry of the Environment, Environment of the Czech Republic: Evolution, Situations, and Trends to the End of 1989 (Prague: Academia, 1990).

Earnhart, Dietrich, "Multiple Penalty Mechanisms in a Principal-Agent Model Under Different Institutional Arrangements," Journal of Comparative Economics 27:1 (1999), 168-189.

Ericson, Richard, "The 'Second Economy' and Resource Allocation Under Central Planning," Journal of Comparative Economics 8:1 (1989), 1-24.

Grossman, G., "The Second Economy of USSR," Problems of Communism 26:5 (1977), 25-40.
Karpoff, Jonathan, and John R. Lott, Jr., "The Reputational Penalty Firms Bear from Committing Criminal Fraud," Journal of Law and Economics 36:2 (1993), 757-802.

Litwack, John, "Legality and Market Reform in Soviet-Type Economies," Journal of Economic Perspectives 5:4 (1991), 77-89.

Maddala, G. S., Limited-Dependent and Qualitative Variables in Econometrics (New York: Cambridge University Press, 1983).

Peterson, D. J., Troubled Lands: The Legacy of Soviet Environmental Destruction (Boulder: Westview Press, 1993).

Půlpán, Daniel, Private conversations with Inspector, Czech Inspection (Prague, Czech Republic, 1993).

Shavell, Steven, "Risk-Sharing and Incentives in the Principal and Agent Relationship," Bell Journal of Economics 10:1 (1979), 55-73.

Svejnar, Jan, The Czech Republic and Economic Transition in Eastern Europe (New York: Academic Press, 1995).

World Bank, "Czech and Slovak Federal Republic Joint Environmental Study: Volumes I-II," report no. 9623-CS (Washington, D.C.: World Bank Publications, 1992). 